\title{
Research into factors influencing students' recognition degree of electronic information majors in higher vocational colleges
}

\author{
She Minghong ${ }^{1, a}$, Yang Hongbing ${ }^{2, b}$ and Tang Jiyong ${ }^{3, a}$ \\ ${ }^{1}$ Computer College, Chongqing College of Electronic Engineering; Chongqing Shapingba,China , \\ 401331,mh_she@126.com \\ ${ }^{2}$ Sichuan Minzu College; Sichuan Kangding 626001,China

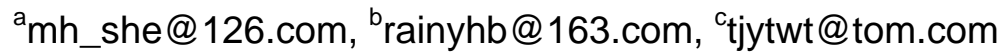

Keywords: higher vocational college; electronic information majors; recognition degree; research Abstract. Under the influence of new situations, China has vigorously promoted construction of the spiritual civilization. During the process, the education situations of higher vocational colleges have been in the spotlight. Higher vocational colleges specialize in bringing up highly professional talents, and are playing an important role in China' s technical development. Recognition degree of students in higher vocational colleges has a great impact on future construction and development of higher vocational colleges. This paper takes electronic information majors in higher vocational colleges as a case study.

\section{Introduction}

The focus of higher vocational colleges is on training professional skills of students in certain aspect. Due to the gap of educational level between higher vocational colleges and undergraduate colleges, enterprises show different recognition degree to learning experiences of students in these two kinds of colleges. The former is committed to seeking an employment for students. However, the current employment rate of graduates of higher vocational colleges is still a far cry from the objective. The gap is largely attributed to lack of recognition on the part of society and students about the learning experiences in higher vocational colleges. This paper adopts electronic information majors as an example. Based on a brief introduction of students' recognition degree of electronic information majors in Chinese higher vocational colleges, the author conducts an in-depth research into the basic factors influencing the recognition degree, and explores how to solve the problem of low recognition degree among students about electronic information majors in higher vocational colleges.

\section{Fundamental factors influencing students' recognition degree of electronic information majors in Chinese higher vocational colleges}

In order to more obviously analyze basic factors influencing students' recognition degree of electronic information majors in higher vocational colleges, the author conducts a questionnaire survey of electronic information majors. Survey results show that: 1) 224 students out of 513 electronic information students are not interested in their major (See Table 1); 2) The major factor influencing students' recognition degree of electronic information majors is social concept. Among 513 students, there are 207 students having a low recognition degree of electronic information majors in higher vocational colleges due to social concept. The specific results are shown in the following Table: 
Table 1 Satisfaction degree of students about electronic information majors in Chinese higher vocational colleges

\begin{tabular}{clclc}
\hline Satisfaction degree & Very satisfied & $\begin{array}{c}\text { Relatively } \\
\text { satisfied }\end{array}$ & Unsatisfied & Very unsatisfied \\
\hline Number of votes & 59 & 126 & 224 & 104 \\
Percentage & $11.5 \%$ & $24.5 \%$ & $43.7 \%$ & $20.3 \%$
\end{tabular}

Table 2 Basic factors influencing students’ recognition degree of electronic information majors in Chinese higher vocational colleges

\begin{tabular}{lccccc}
\hline Basic factors & $\begin{array}{l}\text { Gender } \\
\text { difference }\end{array}$ & $\begin{array}{l}\text { Teachers' } \\
\text { comprehensive } \\
\text { qualities }\end{array}$ & $\begin{array}{l}\text { College } \\
\text { management } \\
\text { level }\end{array}$ & $\begin{array}{l}\text { Social } \\
\text { factors }\end{array}$ & concept \\
\hline $\begin{array}{l}\text { Number of } \\
\text { votes }\end{array}$ & 79 & 145 & 82 & 207 \\
$\begin{array}{l}\text { Percentage } \\
15.4 \%\end{array}$ & $28.2 \%$ & $16.0 \%$ & $40.4 \%$ \\
\end{tabular}

Gender difference. The survey shows that difference of recognition degree caused by gender difference accounts for $15.4 \%$. In recent years, China has been implementing the policy of gender equality. However, gender equality has not yet been fully realized. Through the survey, it can be seen that electronic information majors feature a highly reasonable thinking. Electronic information graduates are expected to provide technical support. However, according to the author's survey, male graduates are more competitive in the employment market compared with female graduates. Many large companies note clearly in their recruitment advertisement that males are preferred. Such phenomena make employment harder for female students. The gender difference in the employment market seems to be an insurmountable gap between female graduates and enterprises [1].

Low comprehensive qualities of teachers for electronic information majors in Chinese higher vocational colleges. Since China's educational system is not complete, the national government does not pay less attention to higher vocational colleges than to undergraduate colleges. Consequently, Chinese higher vocational colleges are in a lower position in China's education undertaking. Those competent teachers prefer undergraduate colleges. The inferior ones are left for higher vocational colleges. The vicious circle results in low comprehensive qualities of teachers teaching electronic information in Chinese higher vocational colleges [2]. Majors related to electronic information techniques are highly professional. Higher vocational colleges are favorable places to bring up highly competent and specialized talents. This is also a feature differing higher vocational colleges from other undergraduate colleges. However, without excellent teachers teaching electronic information techniques, it is hard to develop excellent talents in the field.

Low management level of Chinese higher vocational colleges. Due to lack of national attention to higher vocational colleges, higher vocational colleges themselves are loose in management, which seriously impedes students' development. This is a wrong impression for students and discourages them from working hard to develop themselves. 
Huge social influence on electronic information majors in higher vocational colleges. Through the survey, it is learned that social concept has the greatest influence on students' recognition degree. Previously, students of undergraduate colleges were favored while students of higher vocational colleges were ignored. Parents even had such an idea, that is, without an undergraduate diploma there will be no future. In fact, students of higher vocational colleges have been long infused with such a concept. Therefore, they often give themselves up as hopeless and think that even if they work hard none will encourage them or support them. The social concept will make students lose their bearing [3].

\section{Countermeasures to solve low recognition degree of students about electronic information majors in Chinese higher vocational colleges}

Enhance training of professional skills of teachers in Chinese higher vocational colleges. There is a common problem during the teaching process of Chinese higher vocational colleges. Sometimes, students are full of passion to learn electronic information techniques, but none can help solve their puzzlements. After a long time, students might lose their interest in learning, and even come down with bad habits. All these can seriously influence the development of Chinese higher vocational colleges [4]. Therefore, it is necessary to increase the national attention towards higher vocational colleges and vigorously develop professional skills of the faculty in these colleges.

Change the social concept of Chinese higher vocational colleges. To change the social concept of Chinese higher vocational colleges is the hardest. This has also a research focus in recent years. In order to eliminate such an established concept, the national government should formulate incentive policies and preferential systems targeted at development of higher vocational colleges. The efforts of the national government can change the public concept of higher vocational colleges. Besides, it is necessary to improve the comprehensive strength of higher vocational colleges. As the saying goes, "every cloud has a silver lining." As long as higher vocational colleges increase their comprehensive strength, the public will finally recognize their value.

Improve supervision and management of Chinese higher vocational colleges. To improve students' recognition degree of electronic information majors in Chinese higher vocational colleges, it is important to create a favorable learning atmosphere, strengthen supervision and management of Chinese higher vocational colleges, and forbid slackness. Besides, there should be a strict employment mechanism, punishment and reward system for the faculty team. Students' regulations in higher vocational colleges should also be standardized to serve the practical teaching process. Only in this way can higher vocational colleges embrace a brilliant future [5].

\section{Conclusions}

In this paper, the author investigates into XXX Higher Vocational College, and studies factors resulting in a low recognition degree among students about electronic information majors in Chinese higher vocational colleges. Besides, the author puts forward countermeasures for reform and innovation of higher vocational colleges at an attempt to change people's established concept about higher vocational colleges and boost their development.

\section{Acknowledgements}

This work was supported by Chongqing Education Science and planning issues, project name: Impact Factors and Countermeasures Electronic Information of Higher Vocational Students' professional identity. Project number: 2014-GX-137, Chongqing Municipal Higher Education Teaching Reform of key projects, Project Name: Research and Construction of Electronic Information to Professional Practice Teaching Evaluation System Project Number: 142059, and Chongqing College of Electronic Engineering Education Education Reform Project Project Name: 
Research and Practice relying on skills competition Innovation Network Technology Practice Teaching System Project Number: 201401.

\section{References}

[1] CHEN Zhen. Construction strategies for electronic information majors of vocational colleges oriented towards the industrial posts[J]. Continuing Education, 2013, 08: 46-48.

[2] ZHANG Shuang. Exploration of reform and innovation of teaching practices for electronic information majors in higher vocational education schools[J]. Guangxi Journal of Light Industry, 2014, 05: 102-103.

[3] QIU Jin \& LIU Li. Construction of the English teaching curriculum for electronic information majors in higher vocational education schools based on the occupational development[J]. Journal of Hubei Radio \& Television University, 2014, 08: 18-19.

[4] JIN Ming, GAO Yan, GU Bin, et al. Research and practices of specialized electronic information talent training model for higher vocational schools during the industrial transformational period-Taking the specialized major of Nanjing College of Information Technology as an example[J]. Journal of Innovation and Enterprise Education,2014,02:3-7.

[5] LUO Yichun \& CHEN Zhengzhen. Research and practices of integrated construction of specialized electronic information courses for higher vocational colleges[J]. China CIO News, 2015, 10: 146-147. 